\title{
STTAL DEVELOPMENT STRATEGY TO PRODUCE HUMAN RESOURCES THAT ACKNOWLEDGE TECHNOLOGY FACING THE INDUSTRIAL REVOLUTION ERA 4.0
}

\author{
Ali Mashudi ${ }^{1}$, Abdul Rahman ${ }^{1}$, Adi Bandono ${ }^{1}$, Syaiful Hasan ${ }^{1}$ \\ ${ }^{1}$ Indonesian Naval Technology College, \\ STTAL-Bumimoro-Morokrembangan, Surabaya 60187, Indonesia
}

\begin{abstract}
The industrial revolution 4.0 requires that one must be able to work with increasingly sophisticated technological developments. The industrial revolution 4.0 emphasizes digital economic patterns, artificial intelligence, big data, robotic or known as the disruptive innovation phenomenon. The problem discussed in this study is how to determine the strategy for developing STTAL. The purpose of this study was to determine the best strategy for developing STTAL using the SWOT analysis method. The results of the study show that the development of STTAL to produce Human Resources that mastered the technology faced the era of industrial revolution 4.0. Namely: a). Increase the quantity and quality of laboratory facilities that are complete in stages according to the priority scale adjusting the available budget by means of regulation, cooperation, coordination and socialization to relevant stakeholders, b). Publication of lecturer and student research in national and international journals is one way to improve the ability and expertise to produce technological products of marine and maritime technology, c). Establish a curriculum for each Study Program based on IQF and lead to the science and technology fields of maritime and maritime technology, d). Establishing the ideal STTAL Organization will be able to support the operational education and development of new Cyber Study Programs.
\end{abstract}

Keywords: SWOT Analysis, STTAL Development, Human Resources, Industrial Revolution Era 4.0.

\section{INTRODUCTION}

STTAL is one of the Indonesian Navy's Educational Institutions, which has the task of printing professional Human Resources who master the science of marine technology in the possession of defense equipment. Therefore STTAL must be able to develop itself in an effort to produce the Navy's Human Resources that master the technology of maritime and maritime technology in the face of the era of industrial revolution 4.0.

The industrial revolution 4.0 requires that one must be able to work with increasingly sophisticated technological developments (Xu, David and Kim, 2018). The industrial revolution 4.0 emphasizes digital economic patterns, artificial intelligence, big data, robotic or known as the disruptive innovation phenomenon. Facing these challenges, the teaching system at STTAL is also required to change, including the existence of study programs that produce quality students for future generations.

The laboratory facilities owned by STTAL have not been able to support educational activities in accordance with the Study Program, the research conducted by lecturers and students has not fully received recognition from Intellectual Property Rights and has not been fully published in journals, accredited journals both nationally and internationally, education curriculum regulation is not yet fully based on the Indonesian National Qualifications Framework (KKNI) and marine technology, science in each study program both D-3, S-1 and S-2, STTAL organizations that have not 
accommodated the opening of new study programs (Cyber field). From some of these problems, it is necessary to make an analytical effort to determine the right strategy for STTAL in order to produce TNI HR Aangkatan Laut which controls maritime and maritime technology in the face of the 4.0 industrial revolution era.

To develop STTAL, it can be done by identifying several internal and external factors (Sharif, 2012), and knowing some of the threats and opportunities that exist. The SWOT analysis method can be used to create a development strategy in order to prepare STTAL to print the Navy's Human Resources capable of mastering technology in facing the 4.0 industrial revolution.

This paper has many kinds of literature to support the research, such as literature with title An Extension of Neutrosophic AHP-SWOT Analysis for Strategic Planning and Decision-Making (Basset, Mohammed and Smarandace, 2018), SWOT Analysis of Rural Tourism Development: Case Study of Kampung Tajur, Purwakarta (Mustika and Aditya, 2018), Development SWOT Matrix for Strategic Planning in Media Organizations (Farhangi, Far and danaei, 2012), Hybrid SWOT Approach for Strategic Planning and Formulation in China Worldwide Express Mail Service (Wang, Zhang and Yang, 2014), Dynamic control of the organization strategic plan using SWOT analysis and BSC balanced scorecard (Jafari and Yazdi, 2016), Tourism Development Strategies, SWOT analysis and improvement of Albania's image (Vladi, 2014), Strategic development and SWOT analysis at the University of Warwick (Dyson, 2004).

This research is organized as follows, chapter 1 introduction, chapter 2 shows material and methodology, chapter 3 shows the results of data and discussion, chapter 4 conclusion.

\section{MATERIAL/METHODOLOGY}

\subsection{Organizational Theory.}

An organization is a container or place of administration and management activities that take place with a hierarchical line in the form of position, position, authority, and responsibility (Önday, 2016). In the scope of STTAL in an effort to build an organization to achieve its objectives requires a division of labor with a clear hierarchy of authority. The organizational structure is arranged in a tiered and multilevel manner with command lines and lines of coordination to clarify the reporting flow.

\subsection{Curriculum Management Theory.}

The curriculum is a set of courses that must be given to students who must be studied to achieve educational goals (Bridgeforth, 2005). While curriculum management is a cooperative, comprehensive and systemic curriculum management system covering planning, Supervision of implementation, monitoring, evaluation and improvement, and curriculum development

\subsection{Research Development Theory.}

Management of tertiary institutions in carrying out research and development is very necessary to achieve Research-based tertiary institutions (Rauniar, 2013). The results of the research in the form of industry-based development models that have been tested, evaluated and refined to produce a product will be effective, efficient and quality learning in order to meet the set standards

\subsection{Professionalism Theory.}

Quality human resources will have professional abilities, discipline and high moral integrity (Jecker, 2004). Professional soldiers are trained, educated, well equipped soldiers, not practicing politics, not doing business and guarantee their welfare, as well as following the country's political policies that adhere to the principles of democracy, civil supremacy 
and human rights, national legal provisions and ratified international law. The professionalism of soldiers is a soldier who has the expertise, primary responsibility for the country and a strong character in the corporation. A professional soldier must have knowledge supported by science to be able to organize, plan and direct his activities both in times of war and peace. Warrior professionalism has high moral values and is specifically responsible for society and the state.

\subsection{SWOT Analysis.}

SWOT analysis is an analysis that emphasizes 4 aspects, namely Strength, Weakness, Opportunity, and Threat (Ommani, 2011). This SWOT analysis will identify internal and external factors of the STTAL development strategy so that potentials can be developed in the future and can overcome existing weaknesses. From the internal side, it can be seen the strengths or weaknesses that are owned for the development of STTAL, while from the external side there will be seen opportunities and threats from the outside, after identifying these factors the formulation of the strategy is done using the SWOT method.

\subsection{Strategy Management.}

The strategy is a word with a lot of meaning and everything is relevant and useful to those who are tasked with setting strategies for companies, businesses, or organizations. The strategy comes from Greek, namely Stratego, which is defined as a plan to destroy the enemy by using resources effectively (Rastislav and Silvia, 2015 ).

Management strategies can be defined as the art and science in formulating, implementing, and evaluating cross-functional decisions that enable organizations to achieve their goals. This definition implies that strategic management focuses on integrating management, marketing, finance/accounting, production/operations, research and development, and information systems to achieve organizational success. The term strategic management in this text is used synonymously with the term strategic planning. The latter term is more often used in the business world, while the first is often used in the academic world

\subsection{Research Methodology.}

To solve problems in the observed research, steps are needed and determined to describe the approach and model of the problem. The steps taken are:

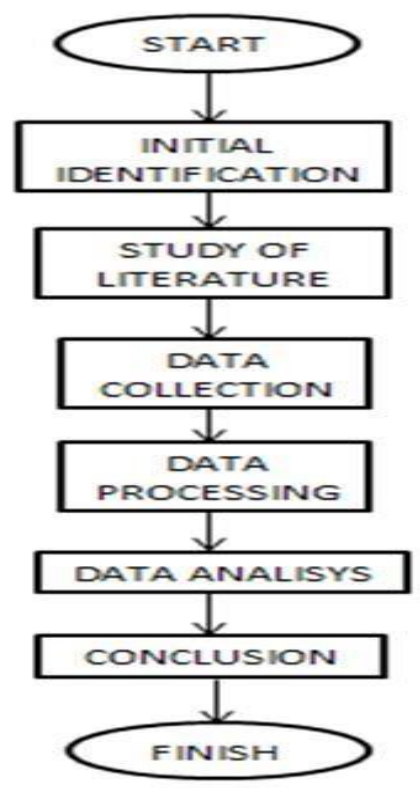

Fig. 1 Research Methodology Flowchart.

Target: The purpose of this research is to determine strategic management for STTAL.

Steps: The step of this research is step 1 to identify problems by looking at internal and external factors, step 2 conducting the analysis, step 3 analyzing the development strategy with SWOT, step 4 giving suggestions for improvement and conclusions. 


\section{RESULT AND DISCUSSION}

\subsection{Analysis, SWOT of STTAL.}

Referring to the goals and objectives of evaluating and implementing the SWOT analysis, it will be known what are the strengths and weaknesses and the development strategies of STTAL and the opportunities that support the development of STTAL and the threats that will be faced in the development.

a. Strength

The definition of Strength in a SWOT analysis is the strength or strength that exists in a company or organization that affects the strategic decision making process. Strengths found in the development of STTAL are 1). STTAL has ongoing organizational governance, leadership, and quality assurance system in accordance with the standards set by Higher Education, 2). STTAL has permanent lecturer resources that have S-2 and S-3 academic qualifications and some lecturers already have a National Lecturer Registration Number, 3). STTAL lecturers and students produce research and community service every year, 4). STTAL is the only official college that concentrates on technology.

b. Weakness

The definition of Weakness in a SWOT analysis is a weakness that exists in a company or organization that affects the strategic decision making process. The weakness found in the development of STTAL is 1). Facilities and infrastructure have not been able to support the activities of education, research and community service in the field of science or technology of maritime affairs and maritime affairs, 2). The research publications produced by lecturers and students have not all entered into international journals. So that it becomes a problem with the recognition of STTAL from the DIKTI in carrying out the Tri dharma of Higher Education, 3). The current organization has not been able to support routine daily operations in carrying out the development of new D-3, S-1, S-2, and S-3 programs. 4). The curriculum in each study program is not all based on KKNI.

\section{c. Opportunity}

The definition of opportunity in a SWOT analysis is an opportunity that exists outside the company or organization that influences the strategic decision making process. The opportunity found in the development of STTAL is 1). The defense budget tends to increase every year, 2). The scholarship program and research funding assistance from LPDP can help with the costs of STTAL research, 3). Maritime Policy from the of the Government, which is essentially maritime technology development, 4). Independent, Accreditation Institutions and Professional Certification Institutions owned by the Navy are able to produce professionalism of soldiers in mastering the technology of maritime and maritime ranks.

\section{d. Threat}

The definition of Threat in a SWOT analysis is a threat that exists outside the company or organization that influences the strategic decision making process. Threats found in the development of STTAL are 1). The existence of official colleges that affect the existence of STTAL, 2). Standardization of Higher Education rules which, if not fulfilled by STTAL results in freezing permits, 3). Limitations of research budget, 4). The private college that offers instant and easy education. 
Table 1. Matrix SWOT

\begin{tabular}{|c|c|}
\hline Strength & Opportunity \\
\hline $\begin{array}{l}\text { - STTAL has sustainable organizational } \\
\text { governance, leadership and quality } \\
\text { assurance systems in accordance with } \\
\text { the standards set by the DIKTI, } \\
\text { - STTAL has permanent lecturer } \\
\text { resources that have S-2 and S-3 } \\
\text { academic qualifications and some } \\
\text { lecturers already have NIDN, } \\
\text { - STTAL lecturers and students produce } \\
\text { research and community service every } \\
\text { year. } \\
\text { STTAL is the only official college that } \\
\text { concentrates on technolog }\end{array}$ & $\begin{array}{l}\text { - Defense budgets that tend to increase } \\
\text { each year, } \\
\text { - A scholarship program and research } \\
\text { funding assistance from LPDP that } \\
\text { can help with the costs of STTAL } \\
\text { research, } \\
\text { - Maritime Policy from the Government } \\
\text { whichessentially develops maritime } \\
\text { technology, } \\
\text { - IndependentAccreditation Institutions } \\
\text { and Professional Certification } \\
\text { Institutions owned by the Navy are } \\
\text { able to produce professionalism of } \\
\text { soldiersinmastering the technology of } \\
\text { maritime and maritime ranks. }\end{array}$ \\
\hline Weakness & Threat \\
\hline $\begin{array}{l}\text { - Facilities and infrastructure have not } \\
\text { been able to support the activities of } \\
\text { education, research and community } \\
\text { service in the science and technology } \\
\text { fields of maritime and maritime affairs. } \\
\text { - Publication of research produced by } \\
\text { lecturers and students has not all } \\
\text { entered into international journals. So } \\
\text { that it becomes a problem with the } \\
\text { recognition of STTAL from DIKTI in } \\
\text { carrying out the Tri dharma of Higher } \\
\text { Education, } \\
\text { - Organizations that currently exist have } \\
\text { not been able to support routine daily } \\
\text { operations in carrying out the } \\
\text { development of new D-3, S-1, S-2 and } \\
\text { S-3 programs. } \\
\text { The curriculum in each Study Program } \\
\text { is not all based on KKNI. }\end{array}$ & $\begin{array}{l}\text { - The existence of official colleges that } \\
\text { affect the existence of STTAL, } \\
\text { - Standardization of DIKTI rules which, } \\
\text { if not fulfilled by STTAL, result in } \\
\text { licensing being frozen, } \\
\text { - Limitations of research budgets, } \\
\text { - Private college that offers instant and } \\
\text { easy education. }\end{array}$ \\
\hline
\end{tabular}

Based on data analysis of strengths, weaknesses, opportunities, and threats that have been obtained, the strategic approach is as follows: Strenght - Opportunities use existing forces to create opportunities, Strength - Threats use existing forces to avoid and eliminate threats - threats, Weakness Opportunities eliminate weaknesses to create opportunities, Weakness - Threat eliminates weaknesses to avoid threats.

Table 2. Strategy approach matrix

\begin{tabular}{|c|c|c|}
\hline & S & w \\
\hline & Strategy S-O & Strategy W-O \\
\hline 0 & $\begin{array}{l}\text { 1. Improve management organizational } \\
\text { governance, leadership and quality assuranco } \\
\text { systems through the existence of LAM and } \\
\text { LSP AL Navy so that they can meet Dikti } \\
\text { standards to improve the professionalism of } \\
\text { soldiers. } \\
\text { 2. Add academic qualifications for S-2 and S- } \\
3 \text { lecturers by utilizing scholarships from } \\
\text { LPDP. } \\
\text { 3. Add research that concentrates on the } \\
\text { technology field by utilizing a defense budget } \\
\text { that increases every year. } \\
\text { 4. Increase the results of STTAL lecturers and } \\
\text { students' research with those related to } \\
\text { marine and maritime technology by utilizing } \\
\text { Indonesia's current maritime policies. }\end{array}$ & $\begin{array}{l}\text { 1. Adding facilities complete laboratory } \\
\text { equipment and facilities through the } \\
\text { defense budget which tend to increase } \\
\text { each year according to the scale of } \\
\text { priority. } \\
\text { 2. Increase publication research into } \\
\text { national and international journals } \\
\text { through research grants and } \\
\text { scholarships from LPDP. } \\
\text { 3. Establish curriculum each Study } \\
\text { Program based on IQF and leads to the } \\
\text { science of technology, maritime and } \\
\text { maritime technology. } \\
4 \text {. Establish / propose an ideal STTAL } \\
\text { Organization so that it can support the } \\
\text { operational education and development } \\
\text { of new Cyber Study Programs. }\end{array}$ \\
\hline & Strategy S-T & Strategy W-T \\
\hline$T$ & $\begin{array}{l}\text { 1. Establish management, leadership and } \\
\text { quality assurance system. } \\
\text { 2. Maximizing Resourœes lecturer with S-2 and } \\
\text { S-3 qualifications to avoid freezing permission } \\
\text { from DIKTI. } \\
\text { 3. Maximizing costs lecturer research in } \\
\text { community service. } \\
\text { 4. Coordinate with Disdikalto be able to order } \\
\text { TNI Navy soldiers at STTAL. }\end{array}$ & $\begin{array}{l}\text { 1. Coordinate and cooperate with other } \\
\text { universities to cooperate in joint } \\
\text { laboratory use. } \\
\text { 2. Maximizing research publications } \\
\text { produced by lecturers and students. } \\
\text { 3. Establish curriculum for each Study } \\
\text { Program based on KKNI. } \\
\text { 4. Maximize existing organizations by } \\
\text { working with Disdikal and other } \\
\text { universities so that they can still meet } \\
\text { DIKTI standards }\end{array}$ \\
\hline
\end{tabular}

Based on the SWOT matrix analysis in Table 3.2 above, we can compile several combination strategies to obtain priority that can be implemented in the effort of developing STTAL to produce human resources who master maritime and maritime technology facing the era of industrial revolution 4.0, namely:

1) Strategy 1. Add complete equipment, facilities, and laboratory facilities through the defense budget, which tends to increase each year, according to the scale of the priority.

This can be done by means of STTAL carrying out Coordination with Srena Mabesal in submitting the budget through RKA-KL to all equipment and infrastructure facilities, laboratories that must be fulfilled in order to support laboratory-based learning in stages.

2) Strategy 2. Increase research publications in national and international journals through research grants and scholarships from LPDP.

This can be done by means of STTAL coordinating with Srena Mabesal to submit a research budget through RKA-KL in the budget for non-operational goods concerning superior research conducted by lecturers and students. 
3) Strategy 3. Establish a curriculum for each Study Program based on IQF.

This can be done by STTAL coordinating and socializing at the Mabesal and Ministry of Defense levels to authorize the submission of an advanced technology, science curriculum consisting of warship technology, science curricula, aircraft technology, science, marine combat vehicle technology, science, maritime safety technology, media technology science, cyber technology science, intelligence technology science and technology science analysis research and operations systems.

4) Strategy 4. Establish the ideal STTAL Organization so that it can support the education operations and development of new study programs.

\section{CONCLUSION.}

From some of the descriptions above, some conclusions can be drawn from the development of STTAL in order to produce human resources who master the technology of maritime and maritime forces facing the era of industrial revolution 4.0. Namely: a). Increase the quantity and quality of laboratory facilities that are complete in stages according to the priority scale adjusting the available budget by means of regulation, cooperation, coordination and socialization to relevant stakeholders, b). Publication of lecturer and student research in national and international journals is one way to improve the ability and expertise to produce technological products of marine and maritime technology, c). Establish a curriculum for each Study Program based on IQF and lead to the science and technology fields of maritime and maritime technology, d). Establishing the ideal STTAL Organization will be able to support the operational education and development of new Cyber Study Programs.

\section{REFERENCES.}

Basset, M.A., Mohammed, M. and Smarandace, F. (2018) 'An Extension of Neutrosophic AHP-SWOT Analysis for Strategic Planning and DecisionMaking', ymmetri Journal, pp. 1-10.

Bridgeforth, B.W. (2005) 'Advancing the Practice of Leadership: A Curriculum ', Journal of Leadership Education, pp. 4-30.

Dyson, R.G. (2004) 'Strategic development and SWOT analysis at the University of Warwick', European Journal of Operational Research, pp. 631640.

Farhangi, A.A., Far, M.S. and danaei, A. (2012) 'Development SWOT Matrix for Strategic Planning in Media Organizations', International Journal of Business and Commerce, pp. 1-12.

Jafari, H. and Yazdi, A.S. (2016) 'Dynamic control of the organization strategic plan using', International Academic Journal of Business Management, pp. 7192.

Jecker, N.S. (2004) 'Tiie Theory and Practice of Professionaiism', The American Journal of Bioethics, pp. 47-49.

Mustika, A. and Aditya, M.K. (2018) 'SWOT Analysis of Rural Tourism Development:Case Study of Kampung Tajur, Purwakarta', Advances in Economics, Business and Management Research , pp. 19-28.

Ommani, A.R. (2011) 'Strengths, weaknesses, opportunities and threats (SWOT) analysis for farming system businesses management: Case of wheat farmers of Shadervan District, Shoushtar Township, Iran ', African Journal of Business Management Vol. 5(22), pp. 9448-9454, 30 September, 2011 , pp. 9448-9454. 
Önday, Ö. (2016) 'Classical Organization Theory:

From Generic Management Of Socrates to

Bureaucrazy Of Weber', International Journal of

Business and Management Review, pp. 87-105.

Rastislav, R. and Silvia, L. ( 2015 ) 'Strategic

Management of Business Performance Based on Innovations and Information Support in Specific Conditions of Slovakia', Journal of Competitiveness , pp. 3-21.

Rauniar, R. (2013) 'Social Media User SatisfactionTheory Development and Research Findings', Journal of Internet Commerce, pp. 195-224.

Sharif, A.S. (2012) 'Islamic Azad University function Analysis with Using the SWOT Model in order to provide Strategic Guidelines (Case Study: Faculty of Humanities) ', Procedia - Social and Behavioral Sciences, pp. $1535-1543$.

Vladi, E. (2014) 'Tourism Development Strategies, SWOT analysis and improvement of Albania's image', European Journal of Sustainable Development, pp. 167-178.

Wang, X.P., Zhang, J. and Yang, T. (2014) 'Hybrid SWOT Approach for Strategic Planning and Formulation in China Worldwide Express Mail Service', Journal of Applied Research and Technology, pp. 11-21.

Xu, M., David, J.M. and Kim, S.H. (2018) 'The Fourth Industrial Revolution: Opportunities and Challenges', International Journal of Financial Research, pp. 9095. 